\title{
РЕЛЕВАНТНА ОЦІНКА НЕРУХОМОГО МАЙНА В МІНІМІЗАЦІЇ ЕКОНОМІЧНОЇ НЕВИЗНАЧЕНОСТІ ПІДПРИЕМНИЦЬКОЇ ДІЯЛЬНОСТІ
}

\author{
Андреєва Віма Анатоліївна, \\ кандидат економічних наук, дочент, \\ дочент кафедри теоретичної та прикладної економіки, \\ ВНЗ Університет економіки та права «КРОК», \\ ORCID: https://orcid.org/0000-0002-6357-3063
}

Анотація. У розділі аналізується проблема релевантної оцінки нерухомого майна в контексті загальної проблеми економічної невизначеності. Автор виходить у своїх міркуваннях про релевантну оцінку з ідеї, що саме така оцінка сприятиме зменшенню зони економічної невизначеності. Здійснено огляд існуючих підходів до оцінки нерухомості з метою акцентування уваги на тих прийомах оцінки, які роблять ії більш досконалим інструментом гарантування економічної стабільності.

Ключові слова: нерухоме майно, ринок нерухомості, оцінка нерухомості, методи оцінки, релевантне оцінювання майна.

Незалежна експертна оцінка майна та майнових прав, яка базується на Національних Стандартах Оцінки, Міжнародних та Європейських Стандартах Оцінки майна та майнових прав, $є$ системним фактором гарантування економічної стабільності. Економічна наука вводить нерухомість у систему свого наукового інтересу, виявляючи в ній специфічні властивості щодо мінімізації економічної невизначеності підприємницької діяльності. На думку економістів, нерухомість $є$ капіталом, поєднаним із землею. Це означає, що цінність та вартість нерухомості обумовлена іiі безпосередньою залежністю від землі. На цьому робили акцент різні дослідники нерухомості $[1 ; 2]$.

Законодавство про оцінку майна $є$ незаперечною інституційною передумовою досягнення вищого рівня визначеності й передбачуваності відносин. Зокрема, Закон України «Про оцінку майна, майнових прав та професійну оціночну діяльність» вимагає певної доведеності результатів оцінки від суб'єктів оціночної діяльності. Оцінка майна, майнових прав - це процес визначення їх вартості на дату оцінки за процедурою, встановленою нормативно-правовими актами з оцінки майна. Він є результатом практичної діяльності суб'єкта оціночної діяльності [3].

Релевантна оцінка нерухомого майна - ознака оцінювання, що зазначена в назві цього розділу - на нашу думку, являє собою рух у бік 
досягнення відповідності між визначеною фахівцями вартістю нерухомого майна та ії дійсною (об’єктивною) ринковою вартістю.

Кожен вид нерухомості має свої особливості функціонування, тому потребує специфічного правового режиму регулювання. Різні види доходу передбачають особливі алгоритми оподаткування. Вони можуть бути пов'язані з частиною вартості нерухомості або з прибутком, що виникає внаслідок функціонування нерухомості.

За критерієм отримання доходу (прибутку), нерухомість, як відомо, поділяється на споживчу, виробничу, комерційну, інвестиційну, дохідну [4].

Споживча нерухомість призначена для постійного (або довготривалого) проживання суб'єктів та розміщення їх власних речей. Ця нерухомість дозволяє користувачам отримувати приховану (альтернативну) ренту. Стосовно саме споживчої нерухомості виникає особливий інституційно-організований суб'єкт володіння - об'єднання власників багатоквартирних будинків, який потрапляє у свій специфічний правовий простір.

Виробнича нерухомість призначена для розміщення різних видів діяльності у сфері промисловості, сільського господарства, транспорту, зв'язку та ін. Дохід від цього виду нерухомості безпосередньо входить у прибуток від основної діяльності. Крім того, певні види виробничої нерухомості (подібно до споживчої) мають приховану ренту, чим обумовлена можливість їх перетворення на комерційну нерухомість.

Комериійна нерухомість призначена для розміщення тих видів господарської діяльності, які безпосередньо пов'язані з наданням послуг споживачам (торговельні приміщення, офіси, кафе тощо). Основна мета розміщення комерційної нерухомості - отримати ренту від місця розташування (де концентрується необхідний рівень купівельної спроможності).

Інвестииійна нерухомість - це всі ті об'єкти (незалежно від призначення), вкладення фінансових ресурсів у які здійснюється 3 метою отримання підприємницького доходу, до складу якого входять прибуток, рента, відсоток. Навколо інвестиційної нерухомості складається багатовимірне економіко-правове середовище. Йдеться про дію механізмів фінансування, іпотечного кредитування. До цього середовища потрапляють операції з цінними паперами, коли фінансування здійснюється шляхом емісії сертифікатів Фонду операцій з нерухомістю.

Функціонування дохідної нерухомості передбачає можливість отримання доходу від передачі об' єктів у різноманітні форми користування. Масштаб операцій з нерухомим майном в Україні постійно зростає. Про це свідчать дані рис. 1 .

Інформація, подана на рис. 1, свідчить про зростання майже у 3 рази за сім років обсягів операцій з нерухомим майном. Це можна інтерпретувати як те, що йдеться про суттєве збільшення привабливості (доходності) цього активу. 


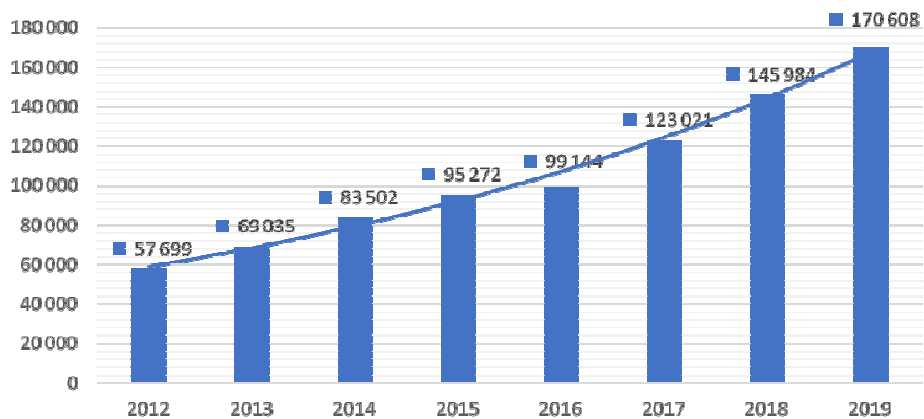

Рис. 1. Операції з нерухомим майном у фактичних цінах, млн грн та їх частка у ВВП, \%

Джерело: власна розробка автора на основі [5].

Користування нерухомістю здійснюється у різноманітних формах. Тільки нерухомості властиві такі особливі форми користування, як:

- фрігольд (користування власником будівлею спільно із землею на необмежений час 3 повною відповідальністю за утримання нерухомості);

- лизгольд (довгострокова оренда з розподілом обов'язків);

- емфітевзис (довгострокова, успадкована оренда сільськогосподарських земель);

- суперфіцій (право забудови землі на необмежений час);

- сервітут (право користування нерухомістю, передане третім особам);

- вертикальний розподіл майнових прав (спеціальні можливості отримання вигоди від підземної частини або повітряного простору).

У сучасних умовах активізується право на придбання обмежених прав на житлові квартири, апартаменти, готельні номери на визначений у договірному порядку проміжок часу (майновий або немайновий таймер). Сьогодні українське законодавство фактично не регулює ці відносини. Вони залишаються у сфері нелегальних відносин, що призводить до різних способів шахрайства.

Формалізований підхід до оцінки ринкової вартості нерухомого майна потребує коректного впровадження для отримання більш доведених результатів, ніж отриманих на основі неформалізованого підходу (суб'єктно-інтуїтивного). Відомі методичні підходи до оцінки нерухомого майна орієнтовані на практичне застосування в умовах стабільної ринкової економіки. Натомість, в Україні такої ринкової стабільності у відносинах немає.

Зазначимо, що сучасні ринкові умови економічної невизначеності створюють для підприємств принципово нові проблеми. Їх вирішення дозволить досягнути та утримати конкурентні позиції на ринку. 
Посилюється усвідомлення того, що розвиток, а отже, і збільшення вартості бізнесу, можливий за рахунок мінімізації економічної невизначеності підприємницької діяльності.

Специфіка вітчизняного ринку нерухомості, який постійно знаходиться в умовах економічної турбулентності, не дозволяє в повній мірі адаптувати відомі міжнародні підходи до оцінки нерухомого майна в реаліях національної економіки. Причинами також є обмеження i недоліки, властиві кожному з класичних підходів до вартісної оцінки майна.

Підходи до оцінки майна розрізняються за своєю спрямованістю та в загальних рисах враховують чинники вартості й практичні аспекти фінансової діяльності, які формуються на основі базової вихідної інформації (табл. 1).

У сфері оцінки нерухомого майна постає питання про узгодження результатів, отриманих за різними підходами для мінімізації економічної невизначеності підприємницької діяльності.

Ситуація на ринку нерухомого майна змушує оцінювачів усе частіше замислюватися про розробку комплексного методу релевантної оцінки нерухомого майна. Йдеться про метод, що враховує різноманітні фактори вартості ще в процесі розрахунків та поєднує переваги кожного 3 класичних підходів. Про це пишуть і теоретики, і практики оціночної справи.

Зважаючи на те, що ефективність оцінки з метою мінімізації економічної невизначеності підприємницької діяльності суттєво залежить від інструментарію іiі проведення, пошук напрямів удосконалення оцінки набуває першочергого значення.

Теоретичним фундаментом методології оцінки майна $є$ системний підхід до визначення основних іiі елементів.

Процес оцінки майна відбувається відповідно до визначеної процедури та за допомогою загальноприйнятих методів оцінки. Таких методів існує декілька. Їх вибір обумовлений насамперед видом об'єкту оцінки та метою, з якою проводиться така оцінка. Для проведення оцінки майна в Україні застосовуються такі основні методичні підходи: дохідний, витратний, порівняльний. Відповідно, дохідний підхід акцентує увагу на доходності, витратний - на активах i зобов'язаннях, порівняльний - на оцінці об'єкта за аналогією з іншими подібними об'єктами.

Оцінка ринкової вартості майна та майнових прав з використанням дохідного підходу базується на визначенні прогнозованого доходу від використання майна. На основі дохідного підходу оцінювач визначає співвідношення майбутніх доходів від об’єкта оцінки та його поточної вартості. До переваг даного підходу насамперед слід віднести його системність.

Сам процес повернення коштів, що були вкладені в об'єкт, може бути як одночасним (наприклад, у момент перепродажу), так і розподіленим 
у часі. Йдеться про те, що основна сума, вкладена в об'єкт, повертається у вигляді періодичних надходжень протягом конкретного проміжку часу.

Таблиия 1

Переваги та недоліки методів оцінки нерухомого майна

\begin{tabular}{|c|c|c|c|}
\hline \multicolumn{2}{|c|}{$\begin{array}{c}\text { Підходи до оцінки нерухомого } \\
\text { майна }\end{array}$} & \multirow[b]{2}{*}{\begin{tabular}{|l|}
\multicolumn{1}{|c|}{ Переваги методу } \\
Використовується для \\
випадків прогнозування \\
постійного за величиною \\
та рівного за періодами \\
прогнозування чистого \\
операційного доходу, \\
отримання якого не \\
обмежено часом
\end{tabular}} & \multirow[b]{2}{*}{\begin{tabular}{|l}
\multicolumn{1}{|c}{ Недоліки методу } \\
Оцінка ризиків є достатньо \\
суб'єктивною в Україні. \\
В основі методу \\
знаходиться прогнозування, \\
а не лише фактична \\
інформація про \\
результати діяльності
\end{tabular}} \\
\hline $\begin{array}{l}\text { Дохідний підхід: } \\
\text { передбачає оцінку } \\
\text { вартості, виходячи } \\
\text { 3 можливостей } \\
\text { об'єкту приносити } \\
\text { дохід }\end{array}$ & $\begin{array}{l}\text { Метод прямої } \\
\text { (лінійної) } \\
\text { капіталізації }\end{array}$ & & \\
\hline & $\begin{array}{l}\text { Метод непрямої } \\
\text { капіталізації } \\
\text { (дисконтування } \\
\text { грошового } \\
\text { потоку) }\end{array}$ & \begin{tabular}{|l} 
Дозволяє оцінити \\
майбутню доходність \\
об'єкта оцінки та врахувати \\
значення об'єкта на ринку \\
виробництва та реалізації \\
послуг \\
\end{tabular} & $\begin{array}{l}\text { В умовах нестабільної } \\
\text { економіки здійснення } \\
\text { точного прогнозування } \\
\text { потребує високої } \\
\text { кваліфікації оцінювачів }\end{array}$ \\
\hline \multirow{2}{*}{$\begin{array}{l}\text { Витратний } \\
\text { (майновий) підхід: } \\
\text { передбачає оцінку } \\
\text { вартості об'єкту, } \\
\text { виходячи з вартості } \\
\text { його відтворення } \\
\text { (заміщення) в } \\
\text { цінах на дату } \\
\text { оцінки з } \\
\text { подальшим } \\
\text { коригуванням на } \\
\text { суму зносу }\end{array}$} & $\begin{array}{l}\text { яямого } \\
\text { ння }\end{array}$ & $\begin{array}{l}\text { Надає можливість } \\
\text { проведення достатньо } \\
\text { точної оцінки витрат, } \\
\text { пов'язаних зі створенням } \\
\text { об’єкта та поелементної } \\
\text { оцінки складових цілісного } \\
\text { об'єкта } \\
\end{array}$ & $\begin{array}{l}\text { Обмежене використання } \\
\text { ринкової інформації } \\
\text { щодо оцінки нерухомого } \\
\text { майна }\end{array}$ \\
\hline & \begin{tabular}{|l|} 
Метод \\
заміщення
\end{tabular} & \begin{tabular}{|l} 
Має нормативно- \\
методичну врегульованість \\
визначення вартості \\
заміщення з подальшим \\
вирахуванням суми \\
зносу (знецінення) \\
\end{tabular} & $\begin{array}{l}\text { Трудомісткість оцінки } \\
\text { об'єктів з більшим } \\
\text { терміном служби через } \\
\text { складність визначення } \\
\text { зносу }\end{array}$ \\
\hline \multirow[t]{2}{*}{$\begin{array}{l}\text { Порівняльний } \\
\text { (підхід аналогів } \\
\text { продажу): } \\
\text { базується на } \\
\text { оцінці вартості } \\
\text { об'єкта, виходячи } \\
\text { 3 вартостей } \\
\text { аналогічних } \\
\text { об'єктів }\end{array}$} & $\begin{array}{l}\text { Метод } \\
\text { галузевих } \\
\text { коєфіцієнтів }\end{array}$ & $\begin{array}{l}\text { Відображає фактично } \\
\text { досягнуті результати } \\
\text { експлуатації об'єктів. } \\
\text { Визначає ціну об'єкта на } \\
\text { основі фактичної ціни } \\
\text { купівлі-продажу } \\
\text { аналогічних об'єктів з } \\
\text { урахуванням корегувань } \\
\text { щодо їх співставлення } \\
\end{array}$ & $\begin{array}{l}\text { Ігнорування перспектив } \\
\text { розвитку об'єкта в } \\
\text { майбутньому. } \\
\text { Трудомісткий збір повної } \\
\text { та достовірної інформації. } \\
\text { Складні коректування в } \\
\text { процесі нівелювання } \\
\text { відмінностей об'єкта } \\
\text { оцінки } \\
\end{array}$ \\
\hline & алогів & $\begin{array}{l}\text { Можливість залучення } \\
\text { апарата математичної } \\
\text { статистики та } \\
\text { комп'ютерного } \\
\text { моделювання }\end{array}$ & $\begin{array}{l}\text { Неможливо використову- } \\
\text { вати, якщо немає } \\
\text { інформації з угод купівлі- } \\
\text { продажу фірм-аналогів } \\
\text { або якщо нерозвинений } \\
\text { ринок купівлі-продажу } \\
\text { підприємств }\end{array}$ \\
\hline
\end{tabular}

Джерело: власна розробка автора на основі [6-8]. 
Фундаментальним для доходного підходу є принцип очікування. Адже саме відповідно до принципу очікування вартість майна визначається дійсною (теперішньою, поточною) цінністю всіх його майбутніх доходів. Логічним виглядає твердження про те, що чим вищий дохідний потенціал оцінюваного майна, тим більша його вартість. При цьому варто пам'ятати лише, що аналіз доходів повинен здійснюватися протягом усього подальшого економічного життя об'єкта оцінки за умови його використання протягом цього періоду часу найбільш ефективним чином.

У відповідності з принципом заміщення максимальна вартість оцінюваного майна не повинна перевищувати найменшу ціну, за якою може бути придбане інше аналогічне майно з еквівалентною дохідністю. Даний принцип за своєю сутністю $є$ аналогом економічного принципу альтернативності інвестицій. Можна стверджувати, що у випадку, коли оцінювач може 3 достатньою точністю спрогнозувати майбутні доходи власника від майна, яке $є$ об'єктом оцінки, протягом конкретно визначеного часу, використання дохідного підходу оцінки є цілком доцільним, а у більшості випадків і абсолютно незамінним.

Основними прийомами даного підходу є:

- метод капіталізації чистого доходу. На його основі визначається потік доходу з перетворенням його в поточну вартість на основі норм капіталізації:

$$
V=\frac{I}{R},
$$

де $V$ - вартість бізнесу; $I$ - чистий дохід; $R$ - норма доходу.

Проте даний метод може дати об'єктивну оцінку винятково в умовах стабільної економіки, за який об'єкт оцінки, наприклад, підприємство протягом тривалого періоду отримувало стабільний дохід;

- метод дисконтування грошового потоку (метод непрямої капіталізації) дає змогу вирахувати поточну вартість майбутніх доходів. Спосіб отримання доходу при цьому значення не має, він може бути отриманий як від володіння самим майном, так і від реалізації майна. Ідеологія методу дисконтованих грошових потоків полягає у тому, що розсудливий інвестор оцінює своє майно 3 погляду доходу таким чином: як можливий дохід, отриманий від експлуатації майна (за період); як реверсію - дохід від об'єкта оцінки, пов'язаний з його продажем у післяпрогнозний період. Це означає, що поточну вартість майна можна розрахувати за формулою [9]:

$$
P V=\frac{I_{1}+R_{1}}{1+i},
$$


де $I_{1}$ - дохід, отриманий від експлуатації майна в кінці першого періоду; $R_{1}$ - реверсія (вартість майна) в кінці першого періоду; $P V-$ поточна вартість майна; $i$ - ставка дисконту (норма доходу на капітал).

Український учений-практик С. Й. Максимов, досліджуючи методи визначення вартості банку, слушно зауважує, що використання дохідного підходу дозволяє найбільш повно врахувати цільові установки діяльності банків, узгоджені з параметрами економічного і соціального розвитку країни загалом та банківської системи зокрема [9].

Деякі зарубіжні вчені вважають, що метод непрямої капіталізації $\epsilon$ найбільш універсальним і достовірним методом оцінювання вартості підприємства. При цьому вчені зазначають, що такий метод найкраще відображає ринкову вартість підприємства. Йдеться про те, що вартість підприємства можна достовірно оцінити лише тоді, коли буде розраховано дохід, який генеруватиметься підприємством у майбутніх періодах [10].

Ми погоджуємося 3 твердженням Т. Коупленда про те, що даний метод не може врахувати низку об'єктивних чинників щодо оцінки майна: інфляцію, коливання курсу валют, інші форс-мажорні обставини. Крім того, джерельною базою для такого методу виступають фінансова та бухгалтерська звітність, дані маркетингового дослідження, стратегія розвитку, перспективні плани тощо. Ця база теж не може гарантувати об'єктивності в проведенні оцінки, адже важко в умовах економічної невизначеності спрогнозувати майбутню вартість готової продукції, устаткування, сировини тощо [11].

Метод дисконтування грошового потоку буде ефективним для застосування щодо підприємств, майнових комплексів, що розвиваються ефективно, характеризуються стабільним доходом, мають довготривалу історію свого функціонування. Він потребує значної кількості коригувань для доведення прогнозованої структури фінансування до реального значення вартості підприємства.

На думку Л. А. Лейфера, практичне застосування методів дисконтування вільних грошових потоків для підприємства, для акціонерного капіталу та активів повинно давати однаковий узагальнюючий показник вартості підприємства [12]. Дані методи дають однакові результати після врахування таких умов:

- в якості вартості акціонерного капіталу та боргів приймається їх ринкова вартість;

- співвідношення між складовими капіталу компанії має бути постійним протягом усього періоду оцінювання;

- темп зростання доходів дорівнює нулю.

Таке твердження може бути адаптоване й до інших сфер господарської діяльності. Але при цьому не вирішується основна проблема - точність розрахунку майбутніх доходів. 
На основі витратного (майнового) підходу переважно відбувається оцінка нерухомого майна, ринок обігу якого $є$ обмеженим (заклади освіти, культури, пам'ятки архітектури тощо).

Для оцінки об'єктів нерухомого майна витратний підхід застосовується за умови необхідності заміщення такого майна чи визначення їхньої економічної доцільності.

Застосування витратного підходу є доцільним за необхідності [13]:

- проведення оцінки державних об'єктів;

- встановлення вартості майна спеціального призначення (школи, лікарні, архітектурні та культурні будівлі, вокзали, відділення зв'язку тощо);

- проведення бухгалтерського обліку;

- встановлення об'єкта оподаткування;

- виставлення майна на аукціон чи інші відкриті торги.

Особливістю такого підходу є проведення оцінки майна винятково на основі аналізу наявних активів. 3 одного боку, це $\epsilon$ перевагою даного методу, адже його результати значною мірою одержано на об'єктивній основі, з іншого боку, даний підхід не враховує перспективи розвитку бізнесу на основі аналізу основних фінансово-економічних показників. Це робить даний метод більш статичним. Він дозволяє визначити нижчий рівень вартості підприємства, майнового комплексу загалом або окремої його частини.

Витратний підхід базується на припущенні, що типовий покупець не запропонує за об'єкт нерухомості кошти більші, ніж сума грошей, яку треба витратити на купівлю земельної ділянки та будівництво на ній об'єкта, аналогічного за своїми споживчими характеристиками нерухомості, що оцінюється.

Розрахунок вартості будівель та споруд у більшості випадків виконується із застосуванням методу оцінки за вартістю одиничного показника, поширеного у вітчизняній оціночній практиці. Однак, необхідно мати на увазі, що він дає розбіжність у 15-20\%. Даний метод грунтується на порівнянні вартості одиниці споживчих властивостей нерухомості (1 м² жилої площі, 1 м $^{3}$ будівельного об'єму і т.п.) оцінюваного об'єкта 3 вартістю аналогічної одиниці виміру подібного типового спорудження.

Задача оцінки полягає в розрахунку залишкової вартості, що являє собою відновну вартість, зменшену на величину зносу. При цьому відновна вартість визначається на основі вартості одиничного показника об'єкта-аналога, а знос, - виходячи з фізичного зносу кожного елемента будівлі, що оцінюється.

Розрахунок здійснюється у такій послідовності:

1.Вибір будівельного аналога.

2. Оцінка вартості об'єкта в цінах, приведених в «Укрупнених показниках відновної вартості» (УПВВ).

3. Визначення відновної вартості. 
4. Розрахунок залишкової відновної вартості.

Вибір аналога здійснюється за допомогою «Укрупнених показників відновної вартості». Вони згруповані в збірниках за галузями народного господарства або за видами будівель і споруд, які містять відновну вартість $1 \mathrm{~m}^{3}$ будівельного об'єму будівлі, 1 км трубопроводу або

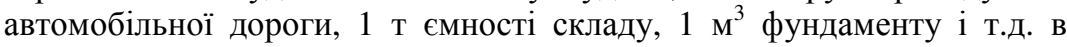
залежності від призначення, конструкції, капітальності, благоустрою, розміру й розташування у визначеному територіальному поясі (для України 2 пояс) з урахуванням кліматичного району.

При визначенні відновної вартості будівлі оціночна вартість одиниці укрупненого вимірника, прийнята за відповідним збірником Укрупнених показників відновної вартості будівель і споруд для 2-го територіального поясу, збільшується на загальну кількість одиниць виміру об'єкта оцінки.

Вартість об' єкта оцінки $\left(V_{\text {repl }}\right)$ при використанні методу розрахунку за вартістю одиничного показника $\left(V_{u n}\right)$ визначається за формулою:

$$
V_{\text {repl }}=V_{\text {un }} \times S(V),
$$

де $V_{\text {repl }}$ - відновна вартість об' єкта оцінки в цінах; $V_{u n}$ - базова вартість одиничного показника відповідно до збірників УПВВ, грн; $S(V)-$ загальна площа (будівельний об'єм) об'єкта оцінки, м $^{2}, \mathrm{~m}^{3}$.

Відновна вартість на дату оцінки не враховує ступеня фізичного зносу і визначається таким чином [6]:

$$
V_{\text {repl.date }}=V_{\text {repl }} \times K_{n},
$$

де $V_{\text {repl.date }}$ - відновна вартість на дату оцінки, грн; $V_{\text {repl }}$ - відновна вартість об'єкта оцінки, грн; $K_{n}-$ інтегральний індекс збільшення вартості будівництва з 1969 р. до дати оцінки.

$$
K_{n}=K_{\text {inc }} \times K_{\text {app }} \times K_{\text {inf }},
$$

де $K_{\text {inc }}$ - коєфіцієнт, який враховує збільшення вартості будівництва; $K_{a p p}$ - ринковий коєфіцієнт подорожчання вартості будівельно-монтажних робіт на території України; $K_{\text {inf }}-$ коєфіцієнт інфляції.

Коєфіцієнт подорожчання $\left(K_{\text {inc }}\right)$ враховує збільшення вартості будівництва і розраховується перемноженням галузевого індексу на територіальний коєфіцієнт.

Ринковий коєфіцієнт подорожчання $\left(K_{\text {app }}\right)$ характеризує зміну вартості будівельно-монтажних робіт. Коєфіцієнт розраховується 3 урахуванням даних Держкомстату України і публікується в збірнику офіційних документів та роз'яснень Державного комітету будівництва і житлової політики України «Ціноутворення в будівництві».

Коєфіцієнт інфляції $\left(K_{\mathrm{inf}}\right)$ використовується у випадку, якщо дата оцінки відрізняється від дати, на яку опублікований ринковий коєфіцієнт 
подорожчання вартості будівельно-монтажних робіт на території України. Він розраховується Держкомстатом України і публікується в періодичній пресі за підсумками кожного місяця.

Визначивши відновну вартість об'єкта, отримуємо його залишкову відновну вартість, яка зменшується на величину зносу та розраховується за формулою [6]:

$$
V_{\text {res }}=V_{\text {repl.date }} \times K_{\text {wear }},
$$

де $V_{\text {res }}$ - залишкова вартість об'єкта, грн; $V_{\text {repl.date }}$ - відновна вартість на дату оцінки, грн; $K_{\text {wear }}-$ коєфіцієнт фізичного зносу.

Величину фізичного зносу характеризує коєфіцієнт фізичного зносу об' єкта, що визначається таким чином:

$$
K_{\text {wear }}=1-\frac{W}{100},
$$

де $K_{\text {wear }}$ - коєфіцієнт фізичного зносу, од.; $W$ - фізичний знос будівлі, \%.

$$
W=\sum_{i=1}^{I} F_{i},
$$

де $F_{i}$ - середньозважений знос елемента будівлі (фундамент, стіни, перекриття і т. ін.).

$$
F_{i}=f_{i} \times l_{i},
$$

де $f_{i}$ - відсоток зносу елемента будинку в залежності від технічного стану; $l_{i}$ - питома вага вартості елемента у вартості всього об'єкта.

Визначення фізичного зносу об'єкта оцінки робиться на базі огляду стану його конструктивних елементів у відповідності до Правил оцінки фізичного зносу жилих будинків, затверджених Держкомітетом 3 житлово-комунального господарства №52 від 02.07.1993 p.

Також, при розрахунках вартості методом витрат необхідною умовою $\epsilon$ врахування вартості земельного компоненту, тобто врахування права користування земельною ділянкою.

Даний підхід дає найбільш достовірні результати, коли оцінюються об'єкти незавершеного будівництва, спеціалізованої нерухомості, а також при оцінці інфраструктури. Менш достовірні результати - при застосуванні цього підходу до оцінки вбудованих приміщень.

Порівняльний підхід у процесі оцінки майна дозволяє зіставити вартість об'єкта оцінки з витратами на придбання аналогічного чи схожого об’єкта. Проте, очевидним є недолік такого методу - пошук аналогічного об'єкта. Це стосується оцінки майна великих промислових комплексів, унікальних споруд, їх територіального розміщення тощо.

У рамках порівняльного підходу (аналогів продажу) дійсне припущення, що дані за угодами, що вже відбулися, є результатом 
суджень продавців та покупців стосовно вартості об'єктів. Вони включають у себе інформацію, яка дозволяє приймати рішення про ринкову вартість об'єкта. В основі підходу лежить принцип заміщення, згідно з яким типовий покупець не сплатить за виставлений на ринку нерухомості об'єкт ціну, більшу ніж витрати на купівлю іншого об'єкта з однаковою корисністю.

У загальному вигляді метод ринкового порівняння (метод аналогів продажу) формалізується таким чином [14]:

$$
V_{o b}=V_{a n} \times K_{\text {diff }},
$$

де $V_{o b}$ - вартість об'єкта оцінки, грн; $V_{a n}-$ вартість аналога, грн; $K_{d i f f}-$ коєфіцієнт, який враховує відмінність об'єкта оцінки від об'єкта-аналога.

Після вибору одиниці порівняння визначаються основні показники або елементи порівняння, використовуючи які можна змоделювати вартість об'єкта оцінки за допомогою необхідних коригувань цін продажу об'єктів-аналогів.

Виходячи з цього, формулюється основне правило коригування при реалізації методу порівняння продажів: коригується ціна продажу об’єкта-аналога для моделювання вартості об'єкта оцінки [15].

Виділяють такі основні елементи порівняння:

- права власності на об'єкт оцінки, що передаються $\left(K_{\text {own }}\right)$. Наявність тих або тих обмежень на право власності об'єктивно знижує вартість об'єкта оцінки, а отже, і ціну продажу;

- умови продажу (вільний продаж, примусовий продаж) $\left(K_{\text {terms }}\right)$. Даний елемент порівняння дозволяє виключити об'єкти порівняння 3 ряду аналогів або провести за ними коректування цін продажів при виявленні відхилень від ринкових умов продажу, зумовлюваних нетиповою мотивацією придбання майна;

- умови фінансових розрахунків при придбанні того або того активу $\left(K_{\text {calc }}\right)$ - угоди купівлі-продажу в аспекті фінансових розрахунків можуть мати різноманітні варіанти, з яких можна виділити два типових:

a) розрахунок покупця з продавцем за рахунок власних коштів i на дату продажу;

б) фінансування угоди купівлі-продажу об'єкта нерухомості самим продавцем, тобто надання ним покупцеві комерційного кредиту (відстрочка платежу);

- динаміка угод на ринку $\left(K_{d y n}\right)$. Цей елемент порівняння дозволяє виявити вплив фактору часу в широкому контексті на динаміку угод на ринку нерухомості й, відповідно, на рівень цін продажів. Складовою фактору часу є інфляція або дефляція, зміни в законодавстві щодо прав власності, оподатковування, зміна попиту та пропозиції на об'єкти нерухомості й інше; 
- місцерозташування $\left(K_{l o c}\right)$. Територіальні координати розміщення того або того об'єкта нерухомості при визначенні його вартості трансформуються в рентну складову вартості. Наприклад, вартість нерухомості залежить від багатьох характеристик, пов'язаних з місцем його розташування, а саме: розбіжності в розташуванні земельних ділянок у різних природнокліматичних зонах, у населених пунктах різних категорій і в межах населених пунктів у різних функціональних й економікопланувальних зонах;

- фізичні характеристики $\left(K_{p h . c h}\right)$ визначають корисність (а отже, і вартість) самого об'єкта оцінки. Перелік фізичних характеристик різноманітні - вік та стан, вид використаних будівельних матеріалів, розмір і форма земельної ділянки (для об’єктів нерухомості), архітектура будинків або спорудження й дизайнерське оформлення інших видів активів та інше.

Таким чином, коєфіцієнт, що характеризує відмінність об'єкта оцінки від об'єкта-аналога можна розрахувати за такою формулою [15]:

$$
K_{\text {diff }}=K_{\text {own }} \times K_{\text {calc }} \times K_{\text {terms }} \times K_{\text {dyn }} \times K_{\text {loc }} \times K_{\text {ph.ch }} .
$$

Даний підхід застосовується, коли $є$ інформація про продаж об'єктів з аналогічними до об'єкта оцінки характеристиками. Враховуючи те, що як первинний, так і вторинний ринки нерухомості на даний час уже сформовано та достатньо інформації про ціни пропозицій аналогів, даний метод визначення вартості $\epsilon$ найбільш достовірним.

Порівняльний підхід реалізується на основі застосування таких методів:

- метод галузевих коєфіцієнтів. Застосування даного методу буде ефективним у випадку системного підходу до його використання. Потрібно вивчити статистичні дані, а також аналітичні узагальнення щодо основних виробничо-фінансових показників підприємства;

- метод компанії-аналога будується на основних засадах бенчмаркінгу і дозволяє на основі вивчення досвіду діяльності аналогічної компанії чи компанії, яка досягла значних успіхів, визначити скоректовану ціну підприємства. Ефективність застосування такого методу залежить від низки чинників: аналог має належати до тієї ж галузі, наближено відповідати за формою управління, географією розташування, видом діяльності, правовою та організаційною структурою, часом функціонування, обсягом виробництва; кількістю працюючих тощо.

Зазначимо, що в міжнародній практиці існує низка методологічних підходів до оцінки нерухомого майна, які в адаптованому вигляді можуть бути імплементовані у вітчизняну практику. Йдеться про модель Едвардса-Белла-Ольсона, (ЕВО) [16]:

$$
V=B_{0}+\sum_{t=1}^{T} \frac{E\left[\Delta X_{t}\right]}{(1+r)^{t^{\prime}}},
$$


де $B_{0}$ - власний капітал (чисті активи) компанії на момент; $E$ - символ математичного очікування; $r$ - ставка дисконтування, яка відповідає очікуваній вартості обслуговуваного капіталу; $\Delta X_{t}-$ відхилення чистого прибутку на момент $\mathrm{t}$ від «норми» (надприбуток).

Модель належить до так званих моделей «залишкового» доходу (Redial Income Model) або RIM. Вважаємо, що модель Ольсона, як одна із перспективних розробок у теорії оцінки майна, синтезує окремі переваги дохідного і витратного підходів. Вона навіть мінімізує недоліки кожного з них, адже оцінка майна відбувається на основі комплексного застосування таких показників:

- балансової вартості в статистичному розрізі за певний період на основі ринкових даних;

- ставки дисконтування;

- величини сплачених дивідендів;

- емпіричних параметрів, значення яких встановлюються за даними всього ринку.

Проте, застосування такої моделі в українських реаліях буде ускладнено низкою проблем, адже дані бухгалтерської звітності вітчизняних компаній переважно не відповідають ринковій вартості. До того ж, можна припустити, що в основі даної моделі закладена постійність волатильності. Це теж ускладнює застосування даних методик в стані економічної невизначеності підприємницької діяльності в Україні.

Отже, можемо зробити припущення, що в даний час немає відповідної методики оцінки майна, апробованої зарубіжним досвідом, яка б забезпечила об'єктивність проведення оцінки нерухомого майна в національних економічних реаліях. Ті методи, підходи, моделі, що $\epsilon$ ефективними в умовах дії міжнародних економічних систем, виявляються не пристосованими до економічних умов в Україні.

Вважаємо, що існує необхідність доповнення національних методичних підходів вимогами щодо збільшення кількості об'єктивної інформації при оцінці нерухомого майна. Наша пропозиція грунтується на власних спостереженнях про відсутність на всіх етапах оцінки як нерухомого майна, так і цілісних майнових комплексів, результатів інтелектуальності власності та інших об'єктів оцінки, об'єктивної, достовірної, своєчасної, цінної, повної інформації про об'єкт оцінки.

У даному контексті ми цілком підтримуємо думку українського вченого-практика С. Й. Максимова, що в умовах інноваційної економіки й швидкого оновлення бізнес-процесів виникає необхідність розкриття у фінансовій звітності інформації щодо стратегії розвитку компанії, яка спрямована на зростання вартості бізнесу і зміцнення його конкурентної переваги. Надання зацікавленим сторонам широкого спектру інформації позитивно позначиться на ринковій капіталізації компаній. 
Безумовно, практичне втілення концепції інформатизації, релевантної оцінки нерухомого майна потребує значних зусиль, насамперед - це формування інформаційних масивів відкритого доступу про об'єкт оцінки. Проте, за умови успішної реалізації та практичного застосування такого підходу, ми зможемо максимально мінімізувати корупційну складову у процесі релевантної оцінка нерухомого майна та дати можливість застосування апробованих міжнародною практикою методів оцінки майна.

Наша пропозиція виходить також із визначених нами основних проблем, 3 якими стикаються на практиці українські оцінювачі. 3 метою мінімізації невизначеності підприємницької діяльності необхідно: по-перше, відкрити інформацію про перспективи розвитку населених пунктів, яка $є$ категорією з обмеженим доступом, як правило, службовою інформацією. По-друге, доцільно систематизувати дані про угоди (маємо на увазі угоди купівлі-продажу). По-третє, необхідно аналогові бази даних про ринкову вартість майна тощо.

Інформаційний підхід в оцінці майна передбачає сукупність певним чином організованих даних про результати господарської діяльності, про різні аспекти, що характеризують функціонування виробничого об' єкта.

Джерельна база інформаційного підходу формується з планових, нормативних, облікових, звітних даних та аналітичної інформації. У структурі інформаційного масиву виділяються відомості про фактичні результати господарської діяльності й про показники в якості бази порівняння.

На основі інформаційного підходу можуть розроблятися матриці SWOT-аналізу, що дозволить спростити процедуру побудови оцінки й забезпечить наочність проведених операцій. Окрім того, важливим джерелом інформації в контексті інформаційного підходу в оцінці майна можуть слугувати геоінформаційні системи (ГІС). На сьогоднішній день мало знайдеться компаній, які не потребували б технологій ГІС. Адже тільки за допомогою цієї системи можливо в найкоротші терміни обробити значну кількість інформації.

Цікавим у розрізі нашого дослідження є досвід Словенії, де 3 використання кредиту Міжнародного банку реконструкції та розвитку, розроблено і впроваджено в дію «Геоінформаційний план підтримки менеджменту нерухомості». Глобальною метою даного проєкту $\epsilon$ забезпечення оперативною підтримкою менеджмент та економіку сектору нерухомості для зміцнення міжнародних зв'язків i використання інформаційних баз даних (земельних реєстрів тощо) та інструментарію, що належить до сучасних інформаційних технологій. Сама методологія у всьому, що стосується збору даних, спроєктована на двох рівнях: дані збираються як на державному рівні, так і на місцевому. 
Але в оцінці майна потрібні не тільки дані з вихідних баз, надані геоінформаційним центром, необхідні також і результати аналізу ринку нерухомості. Оцінка майна 3 використанням ГІС дозволить отримувати наочну інформацію за напрямками нового будівництва, про щільність існуючої забудови міста, з'явиться можливість якісного та кількісного зонування на ринку нерухомості, відображення ділянки на карті міста i конкурентного середовища поблизу нього. Саме геоінформаційні технології дають можливість об'єднати між собою різні види інформації - статистичної, економічної тощо та географічну основу об'єктів. Адже для аналітичної діяльності цифр таблиць буває недостатньо. Тільки поєднання можливостей ГІС і накопиченої оцінювачем аналітичної інформації дає можливість мати повну картину щодо об'єкта оцінки.

Розвиток ринку нерухомості породжує нову трансакційну послугу, яка реалізується завдяки діяльності професійних сервейінгових фірм. Основна функція сервейінгів - забезпечити комплексний підхід до управління нерухомістю на основі розмежування функцій власника (прийняття стратегічного рішення, контроль за якістю) й управлінця (розробка конкретних дій маркетингових досліджень, консультування, інвестування та їх оперативне виконання 3 метою досягнення ефективного результату для власника і суспільства).

\section{Висновки:}

Оцінка нерухомого майна, як процедура зі значним стабілізуючим потенціалом, може використовуватися для обмеження масштабів економічної невизначеності. Саме таку оцінку нерухомого майна можна вважати релевантною для умов національних економік з високим рівнем невизначеності. Саме такою є українська економіка.

Застосовувані у практиці інших країн та в Україні підходи й методики оцінювання нерухомого майна містять окремі елементи, які, у випадку їх реалізації, робитимуть оцінку релевантною. Йдеться про відповідність оцінки тим конкретним умовам, в яких використовується, купується та продається нерухоме майно. Попри важливість загальних підходів до оцінки нерухомого майна, що випливають 3 економічної природи нерухомості, в методиках національної оцінки мають враховуватися й особливі умови.

\section{Лimepamypa:}

1. Маркус I. Я. Посібник з оцінки бізнесу в Україні : навчальний посібник. Київ : Міленіум, 2002. 320 с.

2. Фридман Дж., Ордуэй Н. Анализ и оценка приносящей доход недвижимости. Москва : «Дело Ltd.», 2005. 480 с.

3. Про оцінку майна, майнових прав та професійну оціночну діяльність в Україні : Закон України від 12.07.2001 №2658-III. URL : 
zakon.rada.gov.ua/laws/show/2658-14.

4. Платонов Б. О. Основи оціночної діяльності: навчальний посібник. Київ : НАКККіМ, 2013. 227 с.

5. Офіційний сайт Державної служби статистики України. Основні економічні показники короткострокової статистики будівництва. URL : www.ukrstat.gov.ua.

6. Національний стандарт №1. Загальні засади оцінки майна і майнових прав. URL : zakon.rada.gov.ua/laws/show/1440-2003-п.

7. Національний стандарт №4. Оцінка майнових прав інтелектуальної власності. URL : zakon.rada.gov.ua/go/1185-2007-п.

8. Драпіковський О. І., Іванова I. Б. Оцінка нерухомого майна: дві техніки дохідного підходу. URL : http://irbis-nbuv.gov.ua/cgibin/irbis_nbuv/cgiirbis_64.exe?C21COM=2\&I21DBN=UJRN\&P21DBN= UJRN\&IMAGE_FILE_DOWNLOAD=1\&Image_file_name=PDF/MTP_2 015_58_24.pdf.

9. Максимов С. Й. Оцінка майна для застави та реалізації банківськими установами: навчальний посібник. Київ : Всеукраїнська асоціація фахівців оцінки, 2017. 112 с.

10. Чубка О. М., Федевич Л. С., Курило О. Б. Витратний підхід до оцінки вартості підприємства: характеристика методів. URL : http://economyandsociety.in.ua/journal/19_ukr/179.pdf.

11. Коупленд Т., Коллер Т., Муррин Д. Стоимость компаний. Оиенка и управление. 2005. 360 с.

12. Лейфер Л. А. Точность результатов оценки и пределы ответственности оценщика. URL : http://www.labrate.ru/leifer/lev_leifer_ accuracy_and_appraiser-s_liability-2009-1.htm.

13. Безкоровайна Л. В. Проблеми ідентифікації та оцінки нематеріальних активів. URL : http://visnyk-onu.od.ua/journal/2019_24_ 1/24.pdf.

14. Pagourtzi E., Assimakopoulos V., Hatzichristos T., French N. Real estate appraisal: a review of valuation methods. Journal of Property Investment and Finance. URL : https://www.emerald.com/insight/content/ doi/10.1108/14635780310483656/full/html.

15. Lentovo W., Williams M. Fundamentals of Real Estate Appraisal. URL : https://books.google.com.ua/books?hl=uk\&lr=\&id=3dtj1ymz5EC\&oi=fnd\&pg=PR9\&dq=real+estate+appraisal\&ots=hoom-9SJ81\&sig= rtpdaLw183AWsyPYyNUdPuxoCXY\&redir_esc=y\#v=onepage $\& \mathrm{q}=\mathrm{real} \% 2$ 0estate\%20appraisal\&f=false.

16. Ордов К. В. Использование модели Ольсона для экспрессоценки стоимости компаний. URL : https://www.elibrary.ru/item.asp?id= 26302751. 